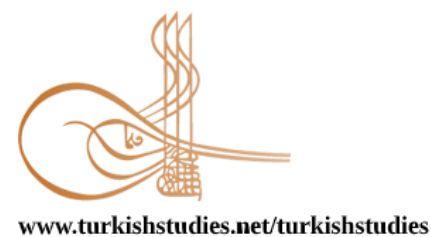

Turkish Studies

\title{
Koronavirüs (Covid-19) Algısının Online Alışverişe Etkisi
}

\author{
The Effect of Coronavirus (Covid-19) Perception on Online Shopping
}

\author{
İnan Kaynak ${ }^{*}$
}

\begin{abstract}
Humanity has experienced lots of pandemic throughout history. The plague pandemic which is thought be originated from China caused roughly 200 million people deaths in 14th century. It is assumed that from 40 to 100 million people died of Spanish flu which out broke at the beginning of 20th century. HIV (AIDS) which outbroke towards the end of 20th century in Africa and took the lives of millions of people. In 21st century, the world experienced SARS, influenza (H1N1), Escherichia coli pandemic, MERS, EBOLA, ZIKA and finally coronavirus (COVID-19) pandemic and again many people were influenced by these diseases. Modern age is an important phenomenon for human in the sense of shopping life. Consumer who were walking and shopping around in classic way came to prefer online shopping which is one of the advantages of internet. It is possible to define online shopping as a system where individuals can purchase various products and services transiently without any means but their devices connected to internet. The main aim of the study is to measure the reflection of disease perception caused by coronavirus pandemic which out broke in People's Republic of China in December and spread through the world on online shopping intention and behaviour of consumers. In this context, an ethical decision was made to be made by the Scientific Research and Publication Board of Muş Alparslan University, dated 29/04/2020 and numbered 20. illness perception questionnaire which was prepared for coronavirus perception and purchase intention scale which was prepared to measure online shopping intention were sent to participants. Regression analysis was done in order to measure the effect of coronavirus (COVID-19) perception on online shopping and it was determined that three sub-dimensions of disease perception predict online shopping intention and one sub-dimension predicts online behaviour.
\end{abstract}

\section{Structural Abstract: Introduction}

The aim of the study is to put forward the effect of coronavirus (Covid-19) on online shopping which started in China and spread throughout the world rapidly.

\section{Purpose}

In the study, the effect of novel coronavirus (covid-19) illness perception on online shopping was analysed. In this scope, answers were sought for these two questions below.

Q1: Does the perception of coronavirus have effect on online shopping intention?

Q2: Does the perception of coronavirus have effect on online shopping behaviour?

\footnotetext{
* Öğr. Gör. Dr., Muş Alparslan Üniversitesi, Malazgirt Meslek Yüksekokul, Finans Bankacıllk ve Sigortacıllk Bölümmü Lecturer, Muş Alparslan University, Malazgirt Vocational School, Finance, Banking and Insurance Department ORCID 0000-0001-9944-1540

i.kaynak@alparslan.edu.tr

Cite as/ Atıf: Kaynak, İ. (2020). Koronavirüs (Covid-19) algısının online alışverişe etkisi. Turkish Studies, 15(4), 633-645. https://dx.doi.org/10.7827/TurkishStudies.44391

Received/Gelis: 21 June/Haziran 2020

Accepted/Kabul: 26 August/Ağustos 2020

Copyright $(\mathrm{C}$ MDE, Turkey
} 
In order to measure this effect; illness perception questionnaire which is composed of four subdimensions namely duration, comprehension of illness, results and emotional representation and purchase intention and behaviour scale which is composed of two sub-dimensions namely purchase intention and purchase behaviour were used.

\section{Conceptual/Theoretical Framework}

The disease which has cases similar to pneumonia and was first observed on 29.12.2019 in Wuhan city in China's Hubei province was related with sea food market in Wuhan. Announcements about the disease was made first by Wuhan Local Health Commission and then by National Health Commission of People's Republic of China and Center for Disease Control and Prevention and it was announced that this is a novel disease which has never been observed before. Between the dates 31.12.2019 and 03.01.2020, 44 cases in total whose causal agents could not be detected were informed to World Health Organisation due to unknown aetiology by national authorities in China. Starting from the first case, there has been drastic increase in the number of cases and the disease turned into pandemic.

This pandemic has indications like Shortness of breath, cough and high fever and is a viral disease which is called novel type coronavirus as a result of studies. As a result of collaborations and consultations of World Health Organisation (WHO), United Nation Food and Agriculture Organization and World Organisation for Animal Health (OIE), World Health Organisation defined the disease as "Coronavirus Disease 2019” for short “COVID-19 (SARS-CoV2 Infection).

The term electronic commerce means electronic generation, distribution, marketing, sales or delivery of goods and services. Ways of e-commerce, market structure and conduction methods in its broadest sense are; Government to Government (G2G), Government to Business (G2B), Government to Consumer (G2C), Business to Business (B2B), Business to Consumer (B2C), Consumer to Government $(\mathrm{C} 2 \mathrm{G})$, Consumer to Business (C2B) and Consumer to Consumer (C2C). Business to Consumer (B2C) type of e-commerce is the most acceptable type of e-commerce.

Consumers who are walking and shopping around stores one by one now also prefer online shopping which is one of the advantages of internet. It is possible to define online shopping as a system where individuals can purchase various products and services transiently without any means but their devices connected to internet.

\section{Method}

Survey method which is one of the quantitative research methods was chosen for the study. The universe of study is composed of 350 people who were got into contact from academic and administrative staff at Muş Alparslan University. For data collection method, a survey of 25 questions adapted from two scales were used apart from demographical questions. Information about scales which were used in order to measure the effect are as such:

Illness Perception Questionnaire: Illness perception questionnaire was developed by Weinmann in 1996 and renewed by Moss-Morris et al. in 2002. This scale was adapted into Turkish by Kocaman et al. in 2007. In order to measure the perception of coronavirus in the study, views about illness dimension of this scale was adapted to coronavirus illness. 18 statements were used in 4 dimensions in this scale. Subdimensions of scale are duration, results, comprehension of illness and emotional representations.

Purchase Intention and Behaviour Scale: For purchase intention the scale of Gugkang (2012) and for purchase behaviour the scale of Wang (2012) and the scale of Patnak and Yaday (2017) were adapted into Turkish by Demirci Otel et al. in 2017. In our study this scale was used in order to measure online shopping intention and behaviour. This scale is composed of two dimensions namely purchase intention and purchase behaviour and of 7 statements.

\section{Findings and Discussion}

Descriptive percentage of regression analysis which was done to measure the effect of coronavirus perception on online shopping intention is $\mathrm{R}^{2=\%} 9$ which is significant. $(\mathrm{F}(4,208)=5.399 ; \mathrm{p}<0,001)$. As a result of the analysis it was detected that from sub-dimensions of disease perception scale duration of disease 
$(\beta=, 001 ; p<0,05)$, results $(\beta=, 034 ; p<0,05)$, and emotional representations $(\beta=, 013 ; p<0,05)$ have positive and significant effect on online shopping intention. In other words, it was detected that sub-dimensions of disease perception scale duration of disease, results and emotional representations increase online shopping intention. From these results $\mathrm{H}_{1 \mathrm{a}}, \mathrm{H}_{1 \mathrm{~b}}$ and $\mathrm{H}_{1 \mathrm{~d}}$ hypotheses were accepted. Also, it was detected that subdimension of disease comprehension $(\beta=, 162 ; \mathrm{p}>0,05)$ has no effect on online shopping. Therefore, $\mathrm{H}_{1 \mathrm{c}}$ hypothesis was denied.

Descriptive percentage of regression analysis which was done to measure the effect of coronavirus perception on online shopping behaviour is $\mathrm{R}^{2=\%} 4$ which is significant. $(\mathrm{F}(4,208)=2.408 ; \mathrm{p}<0,001)$. As a result of the analysis it was detected that from sub-dimensions of disease perception scale results $(\beta=, 028$; $\mathrm{p}<0,05)$ has positive and significant effect on online shopping behaviour. In other words, it was detected that sub-dimensions of disease perception scale results increases online shopping intention. From these results, $\mathrm{H}_{2 b}$ hypothesis was accepted. Also it was detected that from sub-dimensions of disease perception, duration of disease $(\beta=, 179 ; p>0,05)$,disease comprehension $(\beta=, 237 ; p>0,05)$ and emotional representations $(\beta=$ ,330; $p>0,05$ )have no effect on online shopping. Therefore $\mathrm{H}_{2 \mathrm{a}}, \mathrm{H}_{2 \mathrm{c}}$ and $\mathrm{H}_{2 \mathrm{~d}}$ hypotheses were denied.

\section{Results and Recommendations}

Our study was carried out in order to comprehend the extent of coronavirus pandemic's effect on online shopping intention and behaviour. It was determined that duration, results and emotional representations from sub-dimensions of disease perception have an effect on online shopping intention and behaviour but comprehension of disease sub-dimension had no effect on online shopping intention. Results which are a sub-dimension of disease perception had effect on online shopping behaviour but duration, comprehension of disease and emotional representations do not predict online shopping. The study was carried out in Muş where coronavirus cases are relatively low, there has been no curfew in Muş and consumers probably did their shopping in usual ways as they were used to do before pandemic may result in the fact that three sub-dimensions of disease perception could not turn into online shopping behaviour. It is possible to come up with different results if similar studies are carried out in metropolitan cities where restrictions are stricter.

Keywords: Management Organization, Coronavirus, COVID-19, Pandemic, Online Shopping, E-commerce.

Öz: İnsanlık; tarih boyunca birçok salgın hastalıkla karşılaşmışıı. Çin den çıktığı tahmin edilen veba salgını on dördüncü yüzyılda tahminen 200 milyon kişinin ölümüne sebep olmuştur. Yirminci yüzyılın başında ortaya çıkan İspanyol gribinden de 40 ila 100 milyon kişinin öldüğü tahmin edilmektedir. Yirminci yüzyılın sonunda ise Afrika da ortaya çıkan Hiv (Aids) tüm dünyaya yayılmış ve yine milyonlarca insanı hayattan koparmıştır. Yirmi birinci yüzyılda ise sars, influenza (H1N1), Escherichia coli salgını, Mers, Ebola, Zika ve son olarak ta tüm dünyayı etkisine alan koronavirüs (Covid-19) pandemisiyle karşı karşıya kalmış ve yine birçok insan bundan etkilenmiştir. Modern çağ insan için alışveriş yaşamında önemli yer tutan olgulardan biridir. Klasik anlamda mağaza mağaza dolaşıp alışveriş yapan tüketiciler internetin getirdiği faydalardan biri olan online alışverişi de tercih eder duruma gelmişlerdir. Online alışverişi bireylerin internete bağlı cihaz yardımıyla başka bir aracıya ihtiyaç duymadan çeşitli ürünleri ve hizmetleri anlık olarak satın aldıkları bir sistem olarak tanımlamak mümkündür. Araştırmanın temel amacı aralık ayında Çin Halk Cumhuriyetinde ortaya çıkan ve tüm dünyayı etkisi altına alan koronavirüs pandemisinin oluşturduğu hastalık algısının, tüketicilerin online alışveriş niyeti ve davranışına yansımasını ölçmeye yöneliktir. Bu kapsamda Muş Alparslan Üniveritesi Bilimsel Araştırma ve Yayın Etiği Kurulunun 29/04/2020 tarih ve 20 nolu kararınca araştırma yapılması için etik kurul kararı alınmıştır. Koronavirüs algısını ölçmeye yönelik hastalık algısı ölçeği ile online alışveriş niyetini ölçmeye yönelik satın alma niyeti ölçeğinden oluşturulan anket hazırlanarak katılımcılara gönderilmiştir. Koronavirüs (covit-19) algısının online alışverişe olan etkisini ölçmeye yönelik regresyon analizi yapılmış ve hastalık algısının üç alt boyutunun online alışveriş niyetini ve bir alt boyutunun da online davranışı yordadığı tespit edilmiştir.

Anahtar Kelimeler: Yönetim Organizasyon, Koronavirüs, Covit19, Pandemi, Online Alışveriş, E-ticaret 


\section{Giriş}

İnsanoğlu tarih boyunca birçok salgın hastalıkla karşılaşmış ve mücadele etmiştir. Bunlardan şüphesiz en çok bilineni kara ölüm diye adlandırılan "Veba" salgınıdır. Çin den çıktığı tahmin edilen hastalık vebalı cesetlerin savaşta bir silah gibi kullanılmasıyla birlikte dünyanın birçok bölgesine yayılmıştır. Bu yönüyle veba mikrobu dünyada ilk biyolojik harp malzemesi olarak tanımlanabilir. Veba salgını on dördüncü yüzyılda tahminen 200 milyon kişinin ölümüne sebep olmuştur. Yirminci yüzyılın başında ortaya çıkan İspanyol gribinden de 40 ila 100 milyon kişinin öldüğü tahmin edilmektedir. Yüzyılın sonuna gelindiğinde ise sahra altı Afrika da ortaya çıkan Hiv (Aids) tüm dünyaya yayılmış ve yine milyonlarca insanı hayattan koparmıştır. Yirmi birinci yüzyılda ise insanlık yine salgın hastalıklardan Sars, İnfluenza (H1N1), Escherichia coli salgını, Mers, Ebola, Zika ve son olarak ta tüm dünyayı etkisine alan Koronavirüs (Covid-19) pandemisiyle karşı karşıya kalmış ve yine birçok insan bundan etkilenmiştir.

Çin de başladığı varsayılan koronavirüs (Covid-19) pandemisi kısa zamanda Çin sınırlarını aşarak tüm dünyayı etkisi altına almış ve başlangıç yeri olan Çin den daha fazla yıkıma neden olmuştur. Avrupa devletlerinin birçoğu ve Amerika bu salgından ciddi oranda etkilenmiştir. Sağlık sistemleri zayıf olan bazı Avrupa devletlerinde birçok hastaya müdahale edilemediği hatta tedavide kullanılan solunum cihazlarının yetersizliğinden dolayı hasta seçme mecburiyetinde kalındığı bile iddia edilmiştir. Sağlık sistemini bu denli sıkıntıya sokan bu pandemi elbette ki ülkelerin ekonomilerini de etkilemiştir. Ekonomik zararı azaltmak adına farklı tedbirlere başvurmak zorunda kalınmıştır. Birçok ülke pandeminin sorumlusu olarak gördükleri Çin'in bu zararı karşılaması gerektiği yönünde açıklamalar yapmış, ABD yönetimi virüsü koronavirüs değilde "Çin Virüsü" olarak tanımlamak suretiyle gelecekte zararların tazminine yönelik ipuçları da vermiştir. ABD yönetimi bu virüsün laboratuar kaynaklı olduğunu dolayısıyla bir biyolojik silah olduğunu iddia ederken Dünya Sağlık Örgütü bu savı destekleyici kanıtların olmadığını açıklamıştır. Tüm bu olumsuz durumlar ve belirsizlikler işletmeleri de zor durumda bırakmıştır.

Ülkemizde faaliyet gösteren birçok işletmenin faaliyeti devlet otoritesi tarafından durdurulmuştur. Bazı işletmeler ise halk sağlığı gereği faaliyetlerini durdurma ya da üretimlerini azaltma kararı almıştır. Bazı işletmeler online satışlarını bile çalışanlarının sağlıkları açısından durdurduğunu açıklamıştır. İşletmeler belirli dönemlerde küresel veya ülkesel bazı şoklara maruz kalmaktadırlar. Koronavirüs pandemi şoku işletmeler için ciddi bir krize dönüşmüştür. Bu krizi atlatmak isteyen bazı işletmeler online satışa ağırlık vermişlerdir. Bu ve benzeri süreçler online alışverişin işletmeler için önemini bir kez daha ortaya koymuştur.

\section{Kavramsal Çerçeve}

\section{Koronavirüs (Covit-19) Pandemisi}

Çin'in Hubei eyaletine bağlı Wuhan kentinde 29.12.2019 tarihinde görülen pnömoni (Zatürre) benzeri olguları olan hastalık Wuhan da bulunan deniz ürünleri pazarı ile ilişkilendirilmiştir. Hastalıkla ilgili olarak önce Wuhan Yerel Sağlık Komisyonu ardından Çin Halk Cumhuriyetine bağlı Ulusal Sağl1k Komisyonu ve Hastalık Kontrol ve Korunma Merkezince açıklamalar yapılmış ve daha önce görülmeyen yeni bir hastalık olarak duyurulmuştur ( $\mathrm{Li} \mathrm{Q}$, 2020:2). 31.12.2019 - 03.01.2020 tarihlerinde nedensel ajanları tespit edilememiş toplam 44 zatüre olgusu Çin'deki ulusal yetkililer tarafindan bilinmeyen etiyoloji (neden) ile Dünya Sağlik Örgütüne bildirilmiştir(WHO, 2020). İlk vakadan itibaren vaka sayılarında ciddi artışlar gözlemlenmiş ve hastalık salgın haline gelmiştir (Şahin ve Köroğlu, 2020:57).

$\mathrm{Bu}$ yeni salgın hastalık, belirtileri nefes darlı̆̆1, öksürük ve yüksek ateş olan ve yapılan araştırmalar neticesinde yeni tip koronavirüs olarak tanımlanan viral bir hastalıktır (Yeni Koronavirüs Hastalı̆̆ı, 2020). Dünya Sağlık Örgütü (WHO), Birleşmiş Milletler Gıda ve Tarım Örgütü (FAO) ve Dünya Hayvan Sağllğı Örgütü (OIE) işbirliği ve istişareleri neticesinde Dünya 
Sağlık Örgütü Hastalı̆̆ "Koronavirüs Hastalığı 2019” kısaltılması olan "COVID- 19 (SARS-CoV2 Enfeksiyonu)" olarak tanımlamıştır(Ankaralı vd. 2020:2).

Koronavirüsler (CoV), MERS-CoV ve SARS-CoV benzeri ciddi hastalıklara neden olan (WHO, 2020) farkl tiplerde geniş bir virüs gurubudur(Coronavirus, 2020). İlk olarak SARS vakas1 Çin'de Guangdong eyaletinin Foshan şehrinde 2002 tarihinde görülürken(Eraksoy, 2003), yine bir solunum yolu virüsü olan MERS (MERS-CoV) ise ilk olarak 2012 de Suudi Arabistan'da ortaya çıkmıştır(Parlak, 2015:93).

Koronavirüse bağlı ilk ölüm vakasının 11 Ocak 2020 de açıklanmasının ardından 21 Ocak 2020 itibariyle küresel olarak toplam 314 vaka bildirilmiştir. Tayland, Japonya ve Kore Cumhuriyetin' den bildirilen vakaların Wuhan kentine seyahat edenler olduğu açıklanmıştır(WHO, 2019). Yeni koronavirüs acil durum komitesi 30 Ocak 2020 de Uluslararası sağlık tüzüğüne göre toplanıp salgın hastalığın halk sağlığı açısından acil bir durum oluşturduğunu kabul etmiştir. Bu kararın ardından Dünya Sağlık Örgütü (WHO) salgınla ilgili "uluslararası halk sağlığı acil durumu" olduğunu ilan etmiş̧ir(WHO, 2020). İnsandan insana bulaşa bilen salgın hastalık Wuhan kentinden yayılmaya başlamış ardından Hubei Eyaletindeki diğer kentlere ve Çin'in diğer kesimlerine ve dünyada ki bazı ülkelere yayılmıştır. Yeni Koronavirüs (COVID-19), dünyadaki tüm coğrafi bölgelerde, ülkelerin neredeyse tamamında birçok insanı etkisi altına almıştır ve bu etkileri gelecekte de devam edecektir(Başterzi vd., 2020). Dünya Sağlık Örgütü, 11 Mart 2020 tarihinde Yeni Koronavirüs salgının Dünyaya endişe veren yayılımından ötürü pandemi ("bir kita, hatta tüm dünya yüzeyi gibi çok geniş bir alanda yayllan ve etkisini gösteren salgin hastalı) ilan etmiştir(Seyahat Sağlı̆̆ı:2020). Pandemi ilan edilmesinin ardından birçok işletme ve sektör olumsuz etkilenmiştir. Fakat bazı işletmeler için ise firsatlar oluşmuştur. Servis imkanı sunan gıda işletmeleri, kargo firmaları ve ürünlerini internetten satan işletmeler bu kapsamda sayılabilir(Atay, 2020:168).

\section{Online Alışveriş}

Hızla gelişen ve yaygınlaşan teknoloji, beraberinde bilgininde hızlı bir şekilde üretilmesini ve yayılmasını sağlamaktadır. Bu şekildeki bir bilgi yeni toplumsal yapılar ve kültürler oluşturabilmektedir(Tomris Küçün vd., 2018:179). Bilginin hızlı yayıldığı en önemli teknolojik gelişme şüphesiz internettir. İnternet ucuz, hızlı ve küresel anlamda erişme imkanı sunan(Aksoy, 2006:80) ayrıca dünyanın hemen her bölgesinde yaygın bir şekilde kullanılan ve tüm bu özellikleriyle ayrıcalık kazanmış kitle iletişim araçlarından biridir(Çakır ve Topçu 2005:72). Ülkemizde de internettin sağladığı faydalardan ötürü her geçen gün kullanıcı sayısı artmaktadır. Türkiye İstatistik Kurumu, Bilgi Toplumu İstatistikleri 2004-2019, "Girişimlerde Bilişim Teknolojileri Kullanımı Araştırması, Hanelerde Bilişsim Teknolojileri Kullanımı” araştırmasına göre 2004 yılında internet kullanan erkeklerin oranı \% 25.7, kadınların oranı ise 12.1'dir. Bu araştırmanın son verileri yani 2019 yılına göre internet kullanan erkeklerin oranı \% 81,8 , kadınların oranı ise 68,9'dur(TUIK, 2020). Bu rakamlar her geçen gün internet kullanıcı sayısının arttığını göstermektedir. $\mathrm{Bu}$ kullanıcılar interneti farklı sebeplerle tercih etmektedirler. $\mathrm{Bu}$ sebeplerden biri de şüphesiz internetten alışveriştir. İnternetten alışverişin temelleri 1990'ların başında e-ticaret şirketlerinin açılmasıyla beraber atılmaya başlanmıştır(Ateş, 2017:17).

Elektronik ticaret terimi, mal ve hizmetlerin elektronik yollarla üretimi, dağıtımı, pazarlanması, satışı veya teslimatı anlamına gelmektedir(WTO, 2020). E-ticaret biçimleri, piyasa yapıs1 ve yapılış biçimleri itibariyle en geniş tanımıyla; Devletlerarası(G2G), Devlet-İşletme arası (G2B), Kamu-Tüketici arası (G2C), Şirket-Kamu aras1 (B2G), Şirketler arası (B2B), ŞirketTüketici arası (B2C), Tüketici-Kamu arası (C2G), Tüketici-İşletme arası (C2B) ve Tüketiciler arası (C2C) şeklindedir(Coppel, 2020). İşletmelerden tüketicilere (B2C) şeklindeki e-ticaret büyük oranda kabul görmüş e ticaret şeklidir(Algür ve Cengiz, 2011:3667). 
Modern çağ insanın yaşamında önemli yer tutan olgulardan birisi alışveriştir. Alışveriş modern insan için yalnızca fizyolojik ihtiyaç gidermenin dışına çıkarak adeta bir yaşam tarzına dönüşmüştür(Altunışık vd., 2002:56). Klasik anlamda mağaza mağaza dolaşıp alışveriş yapan tüketiciler internetin getirdiği faydalardan biri olan online alışverişi de tercih eder duruma gelmişlerdir. Online alışverişi bireylerin internete bağlı cihaz yardımıyla başka bir aracıya ihtiyaç duymadan çeşitli ürünleri ve hizmetleri anlık olarak satın aldıkları bir sistem olarak tanımlamak mümkündür(Milong, 2010: 709). Modern insan olarak tanımlanan tüketicilerin ihtiyaç temini için yeterli zamanları bulunmamaktadır. Zaman kıstı ve yoğun şehir yaşamında mağazalara ulaşma zorluğundan dolayı tüketiciler online alışverişe yönelmişlerdir(Taşçığlu, 2020:2013).

Online alışveriş yapan tüketicilerin bunu tercih etmesinin bir takım nedenleri vardır. $\mathrm{Bu}$ nedenler klasik alışverişte karş1laşılan kalabalık mağazalardan ve kuyruklarda beklemeden kurtulma, ürünlerin genellikle daha hesaplı olması, ev, iş ve hatta sokakta bile alışveriş yapmanın kolaylığı ve geniş ürün çeşitliliği bunlardan bazılarıdır(Yılmaz, 2016:102). Online alışveriş sahip olduğu bu özellikler ve kolaylıklara ilaveten ödeme imkânlarının çeşitliliği, 7/24 alışveriş yapmaya imkanı sunması, kampanyalardan hızlı biçimde yararlanma ve iade kolaylıkları gibi diğer bazı avantajlara da sahiptir(Karaca ve Gümüş, 2020:53). Online alışverişin bu ve benzeri avantajlarından dolayı dünyada ve ülkemizde her geçen gün tüm alışveriş rakamları içinde payını arttı̆̆ gözlemlenmektedir (Bilgen, 2017:149). Büyümeyi etkileyen bu faktörlere bilgisayar, tablet ve cep telefonu üzerinden internete erişimi artan tüketici sayısının fazla olması da eklenebilir(Altuğ ve Özhan, 2012:1). Online alışverişin yakında ürünlerin tasarlanmasından nihai tüketiciye teslim edilmesine kadar olan bütün süreçlerinin internet ortamında yapılabildiği bir şekle dönüşmesi muhtemeldir(Ağaç vd., 2018:69).

\section{Yöntem}

Araştırmanın temel amacı Çin'de başlayıp çok kısa bir süre içinde tüm dünyayı etkisi altına alan Koronovirüs (Covid 19) hastalığının online alışverişe olan etkisini ortaya koymaktır. Araştırma için nicel araştırma yöntemlerinden anket yöntemi tercih edilmiştir. Araştırmanın örneklemini Muş Alparslan Üniversitesinde çalışmakta olan akademik ve idari personelden iletişim bilgilerine ulaşılmış 350 kişi oluşturmaktadır. Bilgi toplama yöntemi olarak demografik sorular hariç iki ölçekten uyarlanmış toplam 25 sorudan oluşturulmuş anket kullanılmıştır. Anketin uygulanabilmesi için T.C. Muş Alparslan Üniversitesi Bilimsel Araştırma ve Yayın Etiği Kurulunun 29/04/2020 Tarih ve 20 nolu karar sayısı ile etik kurul izni alınmıştır. Verilerin elde edilmesi için google form aracılığıyla oluşturulmuş olan anket katılımcıların mail adreslerine gönderilmiştir. Anket üç bölümden oluşmaktadır. Birinci bölüm demografik soruları içermektedir. İkinci bölüm Koronavirüs algısını ölçmeye yönelik hastalık algısı ölçeğidir. Son bölümde ise Online alışveriş niyetini ölçmeye yönelik satın alma niyeti ve davranışı ölçeklerinden oluşmaktadır. Demografik sorular çoktan seçmeli olarak hazırlanmışken diğer iki bölümdeki ölçeklerin sorularında 5'li Likert ölçeğinden yararlanılmıştır. Anket gönderilen 350 kişinin 213'ünden dönüş alınmış ve tüm sorulara tam ve eksiksiz cevaplar verildiği için ankete katılanların hiç biri araştırmadan çıkartılmamıştır

Ankete katılanlardan elde edilmiş olan veriler SPSS 25.0 istatistik programında analiz edilmiştir. Çalışma ile ilgili verilerin öncelikli olarak geçerlilik ve güvenilirlik analizleri yapılmıştır. Sonraki adımda hipotez testleri için regresyon analizleri yapılmıştır.

\section{Ölçüm Araçları}

Hastalık Algısı Ölçeği: Hasatalık algısı ölçeği, Weinmann tarafından 1996 yılında geliştirilmiş ve Moss-Morris ve ark. tarafından 2002 yılında yenilenmiştir. Bu ölçek 2007 yılında Kocaman ve ark. tarafından Türkçeye uyarlanmıştır. Araştırmada bağımsız değişken olan koronovirüs algısını ölçmek için bu hastalık algısı ölçeğinin hastalık hakkındaki görüşler boyutu koronavirüs hastalığına uyarlanmıştır. Bu ölçekte 4 boyutta 18 ifadeden yararlanılmıştır. Ölçeğin 
alt boyutları süre, sonuçlar, hastalığı anlayabilme ve duygusal temsillerdir. Tüm maddelerin güvenirlilik katsayısı $\alpha=, 521$ 'dir.

Satın Alma Niyeti ve Davranışı ölçeği: Satın alma niyeti için Gugkang (2012)'ın ve satın alma davranışı için Wang (2012) ile Patnak ve Yadav(2017)'ın ölçeklerini Demirci Orel ve arkadaşları 2017 yılında Türkçeye uyarlamıştır. Araştırmamızda online alışveriş niyetini ve davranışını ölçmek için bu ölçekten yararlanılmıştır. Bu ölçek satın alma niyeti ve satın alma davranışı olmak üzere iki boyut ve 7 ifadeden oluşmaktadır. Tüm maddelerin güvenirlilik katsayısı $\alpha=, 909$ 'dir.

Araştırmada kullanılan iki ölçekte 5'li Likert tipindedir. Ölçeklerin aralıkları orijinal şeklindeki gibi "1- Kesinlikle katılmıyorum" ve "5- Kesinlikle katıllyorum" olacak şekilde kodlanmıştır. Ölçekle ilgili dil incelemesi, istatistiki inceleme ve yönetim organizasyon bilimi açısından inceleme alan uzmanlarınca değerlendirilmiş ve herhangi bir sorun olmadığına karar verilince uygulama aşamasına geçilmiştir.

\section{Araştırma Hipotezleri}

Araştımanın temel amacı koronavirüs algısının online alışverişe etkisini incelemektir. $\mathrm{Bu}$ kapsamda koronavirüs algısının alt boyutlarının online alışverişin alt boyutlarına olan etkisini ölçmek için iki ana ve sekiz alt hipotez oluşturulmuştur.

$\mathbf{H}_{1}$ : Koronavirüs algısı online alışveriş niyetini pozitif yönde etkilemektedir.

$\mathrm{H}_{1 \mathrm{a}}$ : Koronavirüs hastalı̆̆ının süre algısı online alışveriş niyetini pozitif yönde etkilemektedir.

$\mathrm{H}_{\mathrm{lb}}$ : Koronavirüs hastalı̆̆ının sonuçları algısı online alışveriş niyetini pozitif yönde etkilemektedir.

$\mathrm{H}_{1 \mathrm{c}}$ : Koronavirüs hastalı̆̆ını anlayabilme algısı online alışveriş niyetini pozitif yönde etkilemektedir.

$\mathrm{H}_{1 \mathrm{~d}}$ : Koronavirüs hastalığı duygusallık algısı online alışveriş niyetini pozitif yönde etkilemektedir.

$\mathbf{H}_{2}$ : Koronavirüs algısı online alışveriş davranışını pozitif yönde etkilemektedir.

$\mathrm{H}_{2 \mathrm{a}}$ : Koronavirüs hastalığının süre algısı online alışveriş davranışını pozitif yönde etkilemektedir.

$\mathrm{H}_{2 \mathrm{~b}}$ : Koronavirüs hastalığının sonuçları algısı online alışveriş davranışını pozitif yönde etkilemektedir.

$\mathrm{H}_{2 \mathrm{c}}$ : Koronavirüs hastalı̆̆ını anlayabilme algısı online alışveriş davranışını pozitif yönde etkilemektedir.

$\mathrm{H}_{2 \mathrm{~d}}$ : Koronavirüs hastalı̆̆ duygusallık algısı online alışveriş davranışını pozitif yönde etkilemektedir.

\section{Bulgular}

\section{Geçerlilik ve Güvenilirlik Analizi}

Araştırmada kullanılan ölçeklerin yapısal geçerlilik ve güvenirliliklerini test etmek amacıyla faktör analizine tabi tutulması gerekmektedir. Hipotezlerimizi kurmamızla ilgili bilgi sağlayacak olan açımlayıcı faktör analizi (AFA) yapılması uygun görülmüştür. Ölçeklerin faktör analizlerine uygunluğunun tespitinden önce KMO ve Bartlett testleri yapılmıştır. Hastalık algısı ölçeğinin faktör analiz değerleri; $\mathrm{KMO}=, 678$ ve Bartlett değeri $\chi^{2}=1954.871 ; \mathrm{p}=, 000<0,05$ 
olarak bulunmuştur. KMO testi sonucunun 0,50 üzerinde ve Bartlett testinin istatistiki açıdan anlamlı bulunmasından dolayı satın alma ölçeğine AFA yapılmasına karar verilmiştir.

Tablo 1:Hastalık Algıısı Ölçeği AFA ve Güvenilirlik Analizleri Sonuçları

\begin{tabular}{|c|c|c|c|c|c|c|}
\hline MADDELER & 1 & 2 & 3 & 4 & $\begin{array}{c}\text { Varyans } \\
\%\end{array}$ & $\begin{array}{c}\text { Cronbach } \\
\alpha\end{array}$ \\
\hline \multicolumn{7}{|l|}{ Hastalık Süre } \\
\hline HS1 & & & .627 & & 11.408 & .72 \\
\hline HS2 & & & .854 & & & \\
\hline HS3 & & & .714 & & & \\
\hline HS4 & & & .720 & & & \\
\hline \multicolumn{7}{|l|}{ Sonuçlar } \\
\hline SNÇ1 & & & & .597 & 7.258 & .69 \\
\hline \multicolumn{7}{|l|}{ SNÇ2 } \\
\hline & & & & .594 & & \\
\hline SNÇ3 & & & & .702 & & \\
\hline SNÇ4 & & & & .606 & & \\
\hline \multicolumn{7}{|c|}{ Hastalığı Anlayabilme } \\
\hline HA1 & & .519 & & & 19.305 & .73 \\
\hline HA2 & & .758 & & & & \\
\hline HA3 & & .806 & & & & \\
\hline HA4 & & .812 & & & & \\
\hline \multicolumn{7}{|c|}{ Duygusal Temsiller } \\
\hline DT1 & .761 & & & & 24.920 & .77 \\
\hline DT2 & .771 & & & & & \\
\hline DT3 & .867 & & & & & \\
\hline DT4 & .612 & & & & & \\
\hline DT5 & .767 & & & & & \\
\hline DT6 & .632 & & & & & \\
\hline
\end{tabular}

Toplam Varyans: \%62.891; Tekrarlama Sayıs1: 6; Döndürme Yöntemi: Varimax; KMO Uygunluk: 0,678; Anlamlılık: $p=, 000$; Goodness of Fit: $\chi 2=1954.871$

Ölçekteki maddelerin ölçeğin toplam varyansını açıklama yüzdesi \%62.891 olarak ölçülmüştür. Ölçek alt boyutların Cronbach's $\alpha$ değerleri ,72,69,73 ve ,77’dir. Bu değerlerden hareketle ölçeğin oldukça güvenilir olduğunu söylemek mümkündür(Tavşancıl, 2010:21).

Satın alma niyeti ve davranışı ölçeğinin faktör analizine uygunluğunu belirlemek için KMO ve Bartlett testleri yapılmıştır. Analiz sonuçlarına göre ölçeğin KMO değeri, 881 ve Bartlett değerinin $\chi^{2}=1046.112 ; \mathrm{p}=, 000<0,05$ olduğu tespit edilmiştir. Bu sonuçlar ölçeğin AFA'ya uygun olduğunu göstermektedir. Satın alma niyeti ve davranışı ölçeğinin AFA sonuçları aşağıda Tablo 2'de verilmiştir. 
Tablo 2:Satın Alma Niyeti ve Davranışı Ölçeği AFA ve Güvenilirlik Analizleri Sonuçları

\begin{tabular}{llccc}
\hline MADDELER & $\mathbf{1}$ & $\mathbf{2}$ & $\begin{array}{c}\text { Varyans } \\
\mathbf{\%}\end{array}$ & $\begin{array}{c}\text { Cronbach } \\
\boldsymbol{\alpha}\end{array}$ \\
\hline Satın Alma Niyeti & & & & \\
\hline SAN1 & .597 & & 65.647 & \\
\hline SAN2 & .746 & & & \\
\hline SAN3 & .909 & & & \\
\hline SAN4 & .850 & & & \\
\hline Satın Alma Davranışı & & & & \\
\hline SAD1 & & .851 & 11.651 & \\
\hline SAD2 & & .738 & & \\
\hline SAD3 & & .946 & & \\
\hline
\end{tabular}

Toplam Varyans: \%77.298; Tekrarlama Sayısı: 3; Döndürme Yöntemi: Varimax; KMO Uygunluk: 0,881; Anlamll1k: $p=, 000$; Goodness of Fit: $\chi 2=1046.112$

Açımlayıcı faktör analizi yapılan satın alma niyeti ve davranışı ölçeğinin maddeleri orijinal ölçek maddelerine uygun dağılımda olduğu tespit edilmiştir. Maddelerin ölçeğin toplam varyansını açıklama yüzdesi \%77.298 ölçülmüştür. Satın alma niyeti ve satın alma davranışı boyutlarının Cronbach's $\alpha$ değerleri ,89 olduğu görülmektedir. Bu değerler ölçeğin oldukça güvenilir olduğunu gösterir. Ölçeklerin normallik dağılımını test etmek için ortalaması alınan hastalık algısı ölçeğinin testi Skewness -,126 ve Kurtosis -,180 olarak bulunmuştur. Online alışveriş niyetini ölçmek için kullanılan satın alma niyeti ve davranışı ölçeği için alınan ortalamaların testinde Skewness -,780 ve Kurtosis, 119 olarak bulunmuştur. Ölçeklere uygulanan çarpıklık ve basıklık değerlerin sonuçları tüm değişkenlerde \pm 1,5 aralığında olduğundan(Tabachnick ve Fidell, 2007:30) verilerimizin normal dağılama uygun olduğu anlaşılmıştır. Tüm değerler araştırma için kullandığımız ölçeklerin güvenilir ölçekler olduğunu göstermektedir. $\mathrm{Bu}$ değerlerden hareketle parametrik testlerin yapılması uygun bulunmuştur.

Araştırma ile ilgili demografik bilgiler şu şekildedir: Araştırmaya katılanların büyük çoğunluğunu $(\% 77,5)$ Erkekler oluşturmaktadır. Ayrıca katılımcıların en yüksek yaş aralığı $(\% 81,6)$ 26-45 yaş aralığından oluşurken gelir düzeyi (\%42.3) 4.501 ile 7.500 arasında olanlardan olduğu, araştırmaya katılanların büyük çoğunluğunun ise öğretim görevlilerinden oluştuğu $(\% 39,4)$ anlaşılmaktadır. Araştırmaya Prof. Dr.' 'ların katılmadığı gözlemlenirken Doçent Dr.'ların ise ankete katılım oranı $(\% 2,8)$ ile en düşük seviyede gerçekleşmiştir.

\section{Hipotezlerin Testi}

Tablo 3:Koronavirüs Algısının Online Alışveriş Niyeti Üzerine Etkisi

\begin{tabular}{|c|c|c|c|c|c|}
\hline Değişkenler ${ }^{a}$ & $\boldsymbol{\beta}$ & $\mathbf{p}$ & $\mathbf{R}^{2}$ & Düz $\mathbf{R}^{2}$ & $\mathbf{F}$ \\
\hline Sabit & 2.751 & .001 & .094 & .077 & 5.399 \\
\hline Hastalık Süre & -.445 & .001 & & & \\
\hline Sonuçlar & .406 & .034 & & & \\
\hline Hastalığı Anlayabilme & -.185 & .162 & & & \\
\hline Duygusal Temsiller & .273 & .013 & & & \\
\hline
\end{tabular}

Koronavirüs algısının online alışveriş niyetine etkisini ölçmeye yönelik olarak yapılan regresyon analizinin modeli açıklama yüzdesi, $\mathrm{R}^{2=} \% 9$ olduğundan anlamlıdır. $(\mathrm{F}(4,208)=5.399$; $\mathrm{p}<0,05)$ Analiz sonucuna göre hastalık algısı ölçeğinin alt boyutlarından hastalık süresi $(\mathrm{p}=, 001$; $\mathrm{p}<0,05)$, sonuçlar $(\mathrm{p}=, 034 ; \mathrm{p}<0,05)$ ve duygusal temsiller $(\mathrm{p}=, 013 ; \mathrm{p}<0,05)$, online alışveriş niyeti üzerinde pozitif yönlü ve anlamlı bir etkiye sahip olduğu tespit edilmiştir. Başka bir ifadeyle 
hastalık algısı alt boyutları olan hasatlık süresi, sonuçlar ve duygusal temsillerin online alışveriş niyetini arttırdığı tespit edilmiştir. $\mathrm{Bu}$ sonuçlardan hareketle $\mathrm{H}_{1 \mathrm{a}}, \mathrm{H}_{1 \mathrm{~b}}$ ve $\mathrm{H}_{1 \mathrm{~d}}$ hipotezleri kabul edilmiştir. Ayrıca hastalığı anlayabilme alt boyutunun $(\mathrm{p}=, 162 ; \mathrm{p}>0,05)$ online alışveriş üzerinde bir etkisinin olmadığ

Tablo 4: Koronavirüs Algısının Online Alışveriş Davranışı Üzerine Etkisi

\begin{tabular}{|c|c|c|c|c|c|}
\hline Değişkenler ${ }^{a}$ & B & $\mathbf{p}$ & $\mathbf{R}^{2}$ & Düz $\mathbf{R}^{2}$ & $\mathbf{F}$ \\
\hline Sabit & 2.508 & .002 & .044 & .026 & 2.408 \\
\hline Hastalık Süre & -.185 & .179 & & & \\
\hline Sonuçlar & .436 & .028 & & & \\
\hline Hastalığı Anlayabilme & -.164 & .273 & & & \\
\hline Duygusal Temsiller & .110 & .330 & & & \\
\hline
\end{tabular}

Koronavirüs algısının online alışveriş davranışı üzerine etkisini ölçmeye yönelik olarak yapılan regresyon analizinin modeli açıklama yüzdesi, $R^{2=} \% 4$ olduğundan anlamlıdır. $(F(4,208)=$ 2.408; $p<0,05)$ Analiz sonucuna göre hastalık algısı ölçeğinin alt boyutlarından sonuçlar $(p=, 028$; $\mathrm{p}<0,05)$ olduğundan online alışveriş davranışı üzerinde pozitif yönlü ve anlamlı bir etkiye sahip olduğu tespit edilmiştir. Başka bir ifadeyle hastalık algısı alt boyutu olan sonuçlar'ın online alışveriş davranışını arttırdığ 1 tespit edilmiştir. Bu sonuçtan hareketle $\mathrm{H}_{2 \mathrm{~b}}$ hipotezi kabul edilmiştir. Hastalık algısı ölçeğinin alt boyutlarından hastalık süresi $(p=, 179 ; p>0,05)$, hastalığı anlayabilme $(\mathrm{p}=, 237 ; \mathrm{p}>0,05)$ ve duygusal temsillerin $(\mathrm{p}=, 330 ; \mathrm{p}>0,05)$ online davranış üzerinde anlamlı bir etkisi bulunamamıştır. Bu sonuçlardan hareketle $\mathrm{H}_{2 \mathrm{a}}, \mathrm{H}_{2 \mathrm{c}}$ ve $\mathrm{H}_{2 \mathrm{~d}}$ hipotezleri reddedilmiştir.

\section{Sonuç}

Koronavirüs pandemisi ortaya çıkış şekli ve yayılım hızıyla diğer pandemilerden oldukça farklı gözükmektedir. Sokağa çıkma yasakları, iller ve ülkeler arasında seyahatlerin durdurulması toplumsal hayatı menfi manada etkilemiştir. Hastalığın yayılmasını engellemeye matuf bu tedbirler birçok işletmenin zor durumda kalmasına neden olmuştur. Bu süreçte ülkemizde çalışanlar için bir takım destekler sağlandığı gibi işletmelerinde bu olağanüstü durumu en asgari hasarla atlatabilmesi için de bazı desteklemeler yapılmıştır. Ayrıca daha fazla müşteriye ulaşmak ve $7 / 24$ satış yapabilmek için online alışveriş kanalları olan işletmelerin salgın döneminde satışa devam edebilmiş olmaları işletmeleri destekleyen başka bir unsur olmuştur.

Araştırmamız koronavirüs salgınının online alışveriş niyetini ve davranışını ne şekilde etkilediğini ölçmeye yönelik olarak yapılmıştır. Hastalık algısının alt boyutlarından üçü olan süre, sonuçlar ve duygusal alt boyutlarının online alışveriş niyetini etkilediği fakat hastalığı anlayabilme alt boyutunun ise online alışveriş niyetini etkilemediği sonucuna varılmıştır. Hastalık algısı alt boyutu olan sonuçların ise online alışveriş davranışını etkilediği ve fakat süre, hastalığ1 anlayabilme ve duygusal temsillerin online alışverişi yordamadığı sonucuna ulaşılmıştır. Çalışmanın koronavirüs vaka sayısının görece az olduğu Muş ilinde yapılmış olması, herhangi bir sokağa çıkma uygulamasının yapılmamış olması ve tüketicilerin pandemi öncesinde yaptıkları gibi alışverişlerini normal yollardan yapmış olma ihtimali hastalık algısının üç alt boyutunun online alışveriş davranışına dönüşmemesi sonucu doğurmuş olabilir. Çalışmanın benzerlerinin ülkemizde kısıtlamaların yoğun bir şekilde uygulandığ 1 metropollerinde yapılması durumunda farklı sonuçlarla karşılaşılması muhtemeldir.

Henüz kesin bir ilacı veya aşısı bulunamamış olan Covid19 Pandemisi tüm dünyada hızla yayılmaya devam etmektedir. $\mathrm{Bu}$ araştırmanın yapıldığı tarihte (03.06.2020) Dünya Sağlık Örgütünün durum raporlarında toplam vaka sayısı 8.525.042 kişi ve toplam vefat sayısı 456.973 kişi olurken Türkiye de bu rakamlar toplam vaka sayısı 186.493 kişi ve toplam vefat sayıs1 4.927 kişi olarak gerçekleşmiştir. Birçok ülke sıkı izolasyon kurallarından ikinci dalga hastalık yayılma 
riskine rağmen vazgeçmeye ve kısmi normalleşmeye başlamıştır. Tabi buradaki amaç uzun vade de toplam enfekte sayısını arttırarak toplumun büyük çoğunluğunun hastalığa karşı bağışıklık kazanmasını sağlamak olabilir. Hastalık boyutundan bakıldığında amaç böyle iken hemen hemen tüm dünya ülkelerini etkisi altına alan bu salgının ülkelerin ekonomilerini de ciddi oranda etkilediği ve bu sebeple "yeni normal" diye tabir edilen mecburi normalleşmeye gidilmesi kaçınılmaz gözükmektedir. İşletmelerin tüm bu durumlardan iyi dersler çıkarması gelecekte olası salgınlara karşı güçlü durabilmesini ve en az zararlarla atlatabilmesini sağlayabilecektir.

$\mathrm{Bu}$ çalışma birçok kişinin ilk defa karşılaştığı küresel bir salgının etkilerinin ve nasıl davranılması gerektiğinin pek bilinmediği bir dönemde online alışveriş niyeti ve davranışını ölçmeye yönelik olarak bir kamu üniversitesi çalışanları üzerinde yapılmıştır. Bu nedenle geneli yansıttığı varsayılamaz. Çalışma enfekte hasta sayısının görece az olduğu ve sokağa çıkma yasaklarının olmadığı bir ilde gerçekleştirilmiştir. Benzer çalışmaların hasta sayısının fazla ve bir takım kısıtlamaların olduğu il veya illerde yapılması önerilmektedir.

\section{Kaynakça}

Ağaç, S., Dengin Sevinir, S. ve Yılmaz, T. (2018). Online Giyim Alışverişinde Tüketicilerin Karşılaştıkları Sorunların Cinsiyet Değişkenine Göre İncelenmesi, Karadeniz Teknik Üniversitesi Sosyal Bilimler Enstitüsü Sosyal Bilimler Dergisi, 8(15), 57-71. https://doi.org/10.14520/adyusbd.572103.

Algür, S. ve Cengiz, F. (2011). Türk Tüketicilere Göre Online (Çevrimiçi) Alışverişin Riskleri Ve Yararlar1, Journal Of Yasar University 2011, 12(24), 3666-3680.

Altuğ, N. ve Özhan Ş. (2012). Trakya Bölgesi’ndeki Üniversitelerde Görev Yapan Öğretim Elemanlarının Online Alışverişten Algıladıkları Risk Ve Fayda Üzerine Bir Araştırma, Öneri Dergisi, 10(38), 1-10. https://doi.org/10.14783/maruoneri.685686.

Altunışık, R., Özdemir, Ş. ve Torlak, Ö. (2002). Modern Pazarlama, Değişim Yayınları

Aksoy, R. (2006). Bir Pazarlama Değeri Olarak Güven Ve Tüketicilerin Elektronik Pazarlara Yönelik Güven Tutumları, ZKÜ Sosyal Bilimler Dergisi, 2(4), 79-90. https://doi.org/10.17755/esosder.97751.

Atay, L. (2020). COVID-19 Salgını ve Turizme Etkileri, Seyahat ve Otel İşletmeciliği Dergisi, 17(1), 168-72. https://doi.org/10.24010/soid.723581.

Ateş, V. (2017). The Scale Of E-Customer Perceptıons: A Study Of Validity And Reliability, Yönetim Bilişim Sistemleri Dergisi, 2(2), 15-31.

Ankaral1, H. Ankaral1, S. ve Erarslan, N. (2020). "Cov1d-19, Sars-Cov2, Infection: Current Epidemiological Analysis And Modeling of Disease". Anadolu Kliniği Tip Bilimleri Dergisi 1(25), 1-22. https://doi.org/10.21673/anadoluklin.707038.

Başterzi, A., Cesur. E., Güvenç R., Taşdelen R., ve Yılmaz, T., (2020). Covıd-19 ve Damgalama, Türkiye Psikiyatri Derneği Ruhsal Travma ve Afet Çalışma Birimi raporu. https://www.psikiyatri.org.tr/uploadFiles/243202019327 DamgalanmaCOVID.pd. https://doi.org/10.5152/kd.2019.51.

Bilgen, İ., ve Zoghi F.S. (2017). A Research on The Impact of Ewom Source Credibility and Personal Innovativeness On Online Shopping Intention in Turkish Customers, Journal of Management, Marketing and Logistics, 4(2), 143-151. https://doi.org/10.17261/pressacademia.2017.458. 
Çakır, H. ve Topçu, H. (2005). Bir İletişsim Dili Olarak İnternet, Erciyer Üniversitesi Sosyal Bilimler Enstitüsü Dergisi, 1(19), 71-96. https://doi.org/10.9775/kausbed.2018.012.

Coppel, J. (2000). E-Commerce: Impacts and Policy Challenges. OECD Economics Department Working Papers No. 252, https://www.oecdilibrary.org/docserver/801315684632.pdf?expires $=1586086074 \mathrm{veid}=\mathrm{idve}$ accname $=$ guestvechecksum $=218478 \mathrm{~B} 7 \mathrm{A7B} 255947 \mathrm{FF} 0 \mathrm{E} 27538 \mathrm{~F} 98623$. https://doi.org/10.1787/801315684632.

Eraksoy, H. (2003). 21.Yüzyılın İlk ve Ağır Bulaşıcı Hastalığı: SARS, Bilim ve Ütopya, 18-25.

Karaca, Ş. ve Gümüş, N. (2020). Tüketicilerin Online Yorum Ve Değerlendirme Puanlarına Yönelik Tutumlarının Online Satın Alma Davranışlarına Etkisi, Sakarya İktisat Dergisi, 9(1), 52-69. https://doi.org/10.24889/ifede.459306.

Li,, Q., Guan, X., Wu. P., Wang, X., Zhou, L., Tong, Y., vd., (2020) Early Transmission Dynamics in Wuhan, China, Of Novel Coronavirus- İnfected Pneumonia. The New England Journal of Medicine, 382(13), 1119-1207

Medicalpark. (2020), Koronavirus, https://www.medicalpark.com.tr/coronavirus/hg-2287\#1,

Milong, L. (2010). The Study of Characteristics of Consumer in Online Shopping ve Related Marketing Strategies of Merchants, Computer Science and Information Technology (ICCSIT), 3rd IEEE International Conference, 4, 709-713. https://doi.org/10.1109/iccsit.2010.5565063.

Özözen Şahin, E. ve Köroğlu, M. (2020). SARS-CoV-2; Virüsün Çevresel Özellikleri, Journal of Biotechnology and Strategic Health Research,(4), 55-64.

Parlak, E. (2015). Middle East Respiratory Syndrome: MERS, Journal of Microbiology and Infectious Diseases, 5(2), 93-98

Tabachnick, B.G., Linda S. F. ve Jodie B.U. (2007). Using Multivariate statistics, (Vol. 5). Boston, MA: Pearson

Taşçıŏlu, M. (2013). Online Alışverişlerde Kargo Hizmetlerinin Tüketici Algılarına Etkisi, Uluslararası Toplum Arasstırmaları Dergisi-International Journal of Society Researches, 15(23), 2011-2030. https://doi.org/10.26466/opus.681809.

Tavşancıl, E.(2010). Tutumların Ölçülmesi ve SPSS ile Veri Analizi, Nobel Akademi.

T.C Sağlık Bakanlığı. (2020), Yeni Koronavirüs Hastalı $\breve{g} l$ Nedir?https://covid19bilgi.saglik.gov.tr/tr/covid-19-yeni-koronavirus- hastaliginedir (Erişim Tarihi: 01.04.2020). https://doi.org/10.30569/adiyamansaglik.716011.

T.C. Sağlık Bakanlığı. (2020), Dünya Sağllk Örgütünün 30.01.2020 Koronavirüs(2019 -Ncov) Durum

Tarihli Yeni https://www.seyahatsagligi.gov.tr/Site/HaberDetayi/2220 (Erişim Tarihi: 06.04.2020

T.C Sağl1k Bakanlığı. (2020), Dünya Sağllk Örgütünün 30.01.2020 Tarihli Yeni Koronavirüs(2019 -Ncov) Durum Raporu, https://www.seyahatsagligi.gov.tr/Site/HaberDetayi/2220 (Erişim Tarihi: 06.04.2020)

Tomris, Küçün, N., Yaman, C. Güngör, S. ve Eroğlu, S. (2018) Online Alışveriş Süreçlerinde Dijital Yerlilerin Ve Dijital Göçmenlerin Stres Düzeylerinin Biyometrik Analizi, Journal of Life Economics, 5(4), 177-190. https://doi.org/10.15637/jlecon.268.

TUIK. (2020), Temel İstatistikler, http://tuik.gov.tr/UstMenu.do?metod=temelist, (Erişim Tarihi: 04.04.2020) 
Yılmaz. V., Arı, E. ve Doğan, R.. (2016) Online Alışverişte Müşteri Şikâyet Niyetleri ve Davranışlarının Yapısal Eşitlik Modeli ile İncelenmesi, Journal of Yasar University, 11(42), 102-112. https://doi.org/10.19168/jyu.60269.

WHO. (2020), Koronavirüs Durum Raporlarl, https://www.who.int/docs/defaultsource/coronaviruse/situation-reports/20200121-sitrep-1-2019ncov.pdf?sfvrsn=20a99c10_4

WHO. (2020), Koronavirüs Durum Raporlarl, https://www.who.int/docs/defaultsource/coronaviruse/situation-reports/20200122-sitrep-2-2019ncov.pdf?sfvrsn=4d5bcbca_2,

WHO. (2020), Koronavirüs Durum Raporlarl, https://www.who.int/docs/defaultsource/coronaviruse/situation-reports/20200130-sitrep-10-ncov.pdf?sfvrsn=d0b2e480_2,

WHO. (2020), Koronavirus, https://www.who.int/health-topics/coronavirus\#tab=tab_1, (Erişim

WTO. (1998).Elektronik ticaret çalışma programı

https://www.wto.org/english/tratop_e/ecom_e/wkprog_e.htm. 